\title{
Effect of different rates of sawdust - piggery compost on soil properties and yield of maize in nutrient depleted soil
}

\author{
Stephen Okhumata Dania *, Adebimpe Omowumi Ayegbe and Bright Ehijiele Amenkhienan \\ Department of Soil Science, Faculty of Agriculture, Ambrose Alli University, Ekpoma, Edo State, Nigeria.
}

World Journal of Advanced Engineering Technology and Sciences, 2021, 03(01), 016-022

Publication history: Received on 11 April 2021; revised on 25 July 2021; accepted on 28 July 2021

Article DOI: https://doi.org/10.30574/wjaets.2021.3.1.0042

\begin{abstract}
Compost is an important source of organic fertilizer that can be used to amend degraded soil to improve soil nutrient and crops yield. This experiment was to evaluate the effect of sawdust - piggery compost on soil properties, growth and yield of maize and it was carried out at the Ambrose Alli University Teaching and Research Farm, Emaudo, Ekpoma, Edo State. The experiment was fitted in a Randomized Complete Block Design (RCBD) with seven treatments and three replicates. The treatments were; control (0), 2, 4, 6, 8, 10 and 12 tonnes of sawdust - piggery compost per hectares (ha1). Data collected were analysed using ANOVA and LSD was used to separate means. Soil nutrients were below critical levels and the application of compost improved fertility status of the soil. Growth parameters, dry matter yield, cob weight, grain yield and nutrient uptake were determined. It was observed that application of Sawdust - piggery compost significantly $(\mathrm{p} \leq 0.05)$ increased the growth of maize compared to control. The application of 8 to 12 tonnes of sawdust - piggery compost significantly $(p \leq 0.05)$ increased the plant height, leaf area and stem girth of maize compared to other treatments. The application of 8 to 12 tonnes per hectares $\left(\right.$ ha $\left.^{-1}\right)$ of sawdust - piggery compost significantly $(p \leq 0.05)$ increased the cob weight, grain and dry matter yield of maize compared to other treatments, however, the application of $10 \mathrm{t} \mathrm{ha}^{-1}$ of compost to maize increased grain yield of maize than others rate of applications with the yield value of $4.60 \mathrm{t} \mathrm{ha}^{-1}$. The uptake of nitrogen, phosphorus and potassium were higher with application of 12 tonnes of compost. In conclusion, the application rates of $10 \mathrm{t} \mathrm{ha}^{-1}$ of sawdust - piggery compost per hectare on nutrient depleted soils will improve the growth and yield of maize.
\end{abstract}

Keywords: Growth; Maize; Nutrient uptake; Compost; Yield

\section{Introduction}

The rising issues of improper disposal of sawdust and piggery wastes resulting to environmental pollution need urgent attention. Waste from piggery farms and timber factory often constitute environmental nuisance and it is therefore necessary to minimize such unpleasant environmental pollutants. Improper disposal of farm waste can be minimize and utilize by harnessing these wastes into compost to ameliorate nutrient depleted soil.

Soil nutrient depletion resulting from degradation reduced the quality of the soil and crop yield, it is important to enhance the fertility of the soil through fertilizer application for higher crop yield. Fertilizers are considered to be a key factor that improves soil nutrient and thereby increase the yield of crops (1). The negative impacts of soil degradation and agricultural sustainability have kindled interest in the assessment of soil quality which is the capacity of the soil to function as living and dynamic nature.

Inorganic fertilizers offer a more reliable form of plant and soil nourishment because its nutrient levels are considered to be consistent. However, mineral fertilizer does not improve soil organic matter which is the key resource in the soil.

${ }^{*}$ Corresponding author: Stephen Okhumata Dania

Department of Soil Science, Faculty of Agriculture, Ambrose Alli University, Ekpoma, Edo State, Nigeria. 
Soil organic matter is an extremely important attribute of soil quality since it influences the soil physical, chemical and biological properties and processes. Although, organic and synthetic fertilizer adds the same nutrient to the soil, however, organic fertilizers perform a dual role by providing required nutrients to plant and increased the soil organic matter (2). Organic manure increases the soil organic carbon pools, soil pH, enhances microbial activities and sustains the ecosystem. Most cultivated soil by tropical farmers lack sustainability due to nutrient losses by soil erosion and unbalanced nutrient mining (3). Achieving high crop yield requires adequate and balanced supply of plant nutrient as declining soil fertility is a prominent contrast for crop production. Maize is a nutrient demanding crop which require adequate and appropriate application of fertilizer for improve growth and yield $(4,5)$. It was therefore the objectives of the study to evaluate the effect of different rate of sawdust-piggery compost on the yield of maize and soil properties.

\section{Material and methods}

\subsection{Description of experimental site}

The experiment was carried out at the Teaching and Research Farm of Ambrose Alli University, Ekpoma, Edo State, Nigeria. Ekpoma is in the humid rainfall vegetation belt of Nigeria, lying between latitude $6^{0} 42^{1}$ North and longitude $6^{0} 8^{1}$ East, with an average annual rainfall of $1500 \mathrm{~mm}$ and temperature between $15^{\circ} \mathrm{C}-34^{\circ} \mathrm{C}$.

\subsection{Collection of soil for analysis}

The top soils $(0-15 \mathrm{~cm})$, were collected from the experimental site prior and after the experiment. The soils were air dried, sieved and the samples were analyzed for both chemical and physical properties. Particle size distribution was determined by hydrometer method (6). The $\mathrm{pH}$ was determined in water (ratio 1:1, soil: water) (7). Organic carbon was determined by wet dichromate method (8), and available phosphorus in the soil was determined using Bray -1 extraction method (9). Total Nitrogen was determined by Kjeldahl method (10). Exchangeable cations; Calcium (ca), magnesium (mg), sodium ( $\mathrm{Na}$ ) and potassium (K) were extracted with $\mathrm{NH}_{4} \mathrm{OAC} \mathrm{pH} \mathrm{7.0} \mathrm{(Ammonium} \mathrm{acetate).} \mathrm{Potassium}$ and sodium were determined with flame emission photometer while calcium (Ca) and magnesium (Mg) were determined by the atomic absorption spectrophotometer (7). Effective cation exchange capacity was determined by the summation of the total exchangeable bases and exchangeable acidity.

\subsection{Plant sample pre-treatment}

Measure $1 \mathrm{~g}$ of the plant material was put into ashing crucible, placed in a muffle furnace, switched on and allowed to stand at the prescribed temperature for 3 hours. Then switched off and allow to cool down just enough to touch, recovered from the furnace, add $10 \mathrm{ml}$ and $20 \%$ Nitric acid and filtered into $100 \mathrm{ml}$ standard flask, make up to volume with distilled water and determine potassium $(\mathrm{K})$ with flame photometer through a set of working standards of the order $0,2,4,6,8$ and 10ppm respectively to calibrate the equipment while the phosphorus content was by blue ammonium molybdate method (Standard Method).

Nitrogen $(\mathrm{N})$ was determined by regular macro Kjedahl method where $0.1 \mathrm{~g}$ of the plant sample was accurately weighed into digestion tube, $2 \mathrm{ml}$ of concentrated Sulphuric acid and 1 tablet of selenium catalyst was added and digested on the Hot plate until the solution becomes clear and allowed cool down and filtered into $100 \mathrm{ml}$ standard flask, make to volume with distilled water and determined the Nitrogen content with its standard method.

\subsection{Experimental design and application of compost}

The experimental design was Randomized Complete Block Design (RCBD) with seven treatments, replicated three times. The treatments which also represent the rate of application were; control 2, 4, 6, 8, 10 and 12 tonnes of sawdustpiggery compost and were applied two weeks after germination.

\subsection{Land preparation and management operation}

Land preparation (clearing, packing and mapping out) was done manually. Planting area was $16 \mathrm{~m} \times 16 \mathrm{~m}$. The trial was laid in 21 plots with each plot measuring $1.8 \mathrm{~m} \times 1.8 \mathrm{~m}$. Planting was done at the rate of three seeds per stand at a planting distance of $75 \mathrm{~cm} \times 25 \mathrm{~cm}$ within and between rows and later thinned two weeks after planting to one plant per stand with a population of 53,333 plants per hectare. Weeding was done manually; harvesting and above ground biomass was determined. 


\subsection{Data collection}

The following data were collected; height $(\mathrm{cm})$, Leaf Area $\left(\mathrm{cm}^{2}\right)=\mathrm{L} \mathrm{X} \mathrm{WX} 0.75(11)$, Stem girth (mm) was measured using vernier caliper $4-8$ weeks after planting. Cob weight $\left(t \mathrm{tha}^{-1}\right)$, Grain yield $\left(\mathrm{t} \mathrm{ha}^{-1}\right)$ Dry matter yield $(\mathrm{t}$ ha-1).

$$
\text { Nutrient uptake }=\text { Dry matter yield }(\mathrm{kg}) \times \text { Nutrient content }(\%)
$$

Data collected were analyzed statistically using Analysis of variance (ANOVA) and means separated using the LSD.

\section{Results and discussion}

\subsection{Soil Analysis}

The initial $\mathrm{pH}$ value of the soil before planting was 5.7 while after application of sawdust - piggery compost the pH ranged from 6.3 in 2 tonnes to 6.6 in 12 tonnes and these were higher compared to control with the value of pH 5.4. This result corresponds with the earlier work (12), who reported that organic matter has the ability to buffer acidity and (13), they reported an increase to near neutral in $\mathrm{pH}$ when soil was amended with compost. The organic carbon in soil amended with sawdust - piggery compost were higher compared to control, it ranges from $16.42 \mathrm{~g} / \mathrm{kg}$ in 2 tonnes to $21.70 \mathrm{~g} / \mathrm{kg}$ in 10 tonnes of sawdust - piggery compost application. Available phosphorus ranges from 14.8 in control to 40.4 from the application of 10 tonnes of sawdust - piggery compost. Calcium level ranged from $2.18 \mathrm{cmol} / \mathrm{kg}$ in 2 tonnes to $3.45 \mathrm{cmol} / \mathrm{kg}$ in 8 tonnes of sawdust - piggery compost and were below the critical level of $3.80 \mathrm{cmol} / \mathrm{kg}$. However, the application of 10 and $12 \mathrm{t} \mathrm{ha}^{-1}$ were above the critical value. Sodium content of the initial soil sample was lower compared to soil amended with sawdust - piggery compost but were all below the critical level of $10 \mathrm{cmol} / \mathrm{kg}$. The critical level of magnesium is $2.00 \mathrm{cmol} / \mathrm{kg}$, the initial soil sample, control and soil amended with 2 tonnes of sawdust - piggery compost had magnesium content lower that the critical level. Other treatments applied have a higher concentration of magnesium higher than the critical level. The nitrogen content of soil amended with sawdust - piggery compost were higher compared to the initial and the control soil samples. Soil amended with 10 tonnes of sawdust piggery compost had the highest nitrogen content of $8.08 \mathrm{~g} / \mathrm{kg}$ compared to other treatments. The application of 8 - 12 t ha $\mathrm{a}^{-1}$ increased the nutrient content of the soil than other treatments. The particle size distributions of soil before and after application of sawdust - piggery compost were sandy loam.

\subsection{Growth parameters}

It was observed that the application of sawdust - piggery compost increased the height of maize compared to control (Table 2). The application of eight to twelve tonnes of sawdust - piggery compost significantly ( $\leq \leq 0.05)$ increased the height of maize compared to other treatments. According to (14), the applications of organic manure significantly $(\mathrm{p} \leq 0.05)$ increased the growth of maize than the control or application. Also (15) reported that, compost is a rich source of plant nutrient especially nitrogen, phosphorus and sulphur which are necessary nutrients required for healthy plant growth.

The application of Sawdust - piggery compost significantly $(\mathrm{p} \leq 0.05)$ increased the stem girth of maize at six, seven and eight weeks after planting compared to the control (Table 2). There was no significant ( $\leq \leq 0.05$ ) difference in stem girth at fourth weeks after planting. (16) reported no significant $(\mathrm{p} \leq 0.05)$ difference in stem girth at the initial application of organic manure to maize due to slow mineralization. However, at six to eight weeks after planting, the application of eight to twelve tonnes of sawdust - piggery compost significantly $(p \leq 0.05)$ increased the stem girth of maize. These findings agreed with (17), that organic fertilizer increases the fertility of soil and improve crop growth due to nutrient availability and release (Table2).

The leaf area of maize was enhanced with the application of sawdust - piggery compost (Table 2). It was observed during the growth period, the leaf area of maize increased on soil amended with sawdust - piggery compost were significantly compared to control. At six to eight weeks after planting, the leaves area were significantly ( $\mathrm{p} \leq 0.05)$ higher with the application of eight to twelve $\mathrm{tha}^{-1}$ of compost compared to other treatments applied. The results confirms the earlier works of (18), they reported that the leaf area of maize were significantly $(\mathrm{p} \leq 0.05)$ increased by the application of compost at different levels. It therefore evidence that the application of sawdust - piggery compost significantly improved the leaf area of maize. The application of twelve tonnes of sawdust - piggery compost increased the leaf area of maize than other treatments. The ability of compost to improve water absorption in soil helps plants to absorb nutrients sufficiently for growth and expansion of leaves (19). 
Table 1 Soil and Compost Analysis

\begin{tabular}{|c|c|c|c|c|c|c|c|c|c|c|c|c|c|c|c|c|c|}
\hline Treatments & \begin{tabular}{|l|} 
OC \\
$\mathrm{g} / \mathrm{kg}$ \\
\end{tabular} & pH & \begin{tabular}{|l} 
N \\
g/kg \\
\end{tabular} & $\begin{array}{l}\mathrm{P} \\
\mathrm{Mg} / \mathrm{kg} \\
\end{array}$ & Ca & Mg & $\mathrm{Na}$ & $\stackrel{\mathrm{K}}{\longrightarrow}$ & \begin{tabular}{|l} 
CEC \\
$\mathrm{Cmol} / \mathrm{kg}$
\end{tabular} & ECEC & Al & H & EA & Sand & \begin{tabular}{|l} 
Silt \\
g/kg 4
\end{tabular} & Clay & \begin{tabular}{|l} 
Soil \\
Texture
\end{tabular} \\
\hline ISS & 1.60 & 5.7 & 1.24 & 16.21 & 2.32 & 1.59 & 0.71 & 0.07 & 4.69 & 5.29 & 0.08 & 0.51 & 0.60 & 820 & 30 & 150 & Sandy Loam \\
\hline $\mathrm{C}$ & 1.24 & 5.4 & 1.20 & 14.80 & 2.18 & 1.12 & 0.63 & 0.03 & 4.36 & 4.96 & 0.07 & 0.49 & 0.60 & 825 & 25 & 150 & Sandy Loam \\
\hline $2 t$ & 26.42 & 6.3 & 5.72 & 29.50 & 2.84 & 1.89 & 1.32 & 0.05 & 6.11 & 6.61 & 0.07 & 0.43 & 0.50 & 860 & 20 & 120 & Sandy Loam \\
\hline $4 \mathrm{t}$ & 26.53 & 6.4 & 7.18 & 34.91 & 3.29 & 2.46 & 1.34 & 0.04 & 7.52 & 7.92 & 0.06 & 0.34 & 0.40 & 850 & 20 & 130 & Sandy Loam \\
\hline $6 \mathrm{t}$ & 28.96 & 6.4 & 7.24 & 40.01 & 3.38 & 2.12 & 1.21 & 0.06 & 6.56 & 6.96 & 0.11 & 0.29 & 0.40 & 830 & 30 & 140 & Sandy Loam \\
\hline $8 \mathrm{t}$ & 27.99 & 6.5 & 7.41 & 29.91 & 3.46 & 2.04 & 1.25 & 0.06 & 6.41 & 6.81 & 0.04 & 0.36 & 0.40 & 820 & 30 & 150 & Sandy Loam \\
\hline $10 \mathrm{t}$ & 28.70 & 6.6 & 8.08 & 40.41 & 4.86 & 2.04 & 1.56 & 0.06 & 7.32 & 7.72 & 0.03 & 0.37 & 0.40 & 830 & 30 & 140 & Sandy Loam \\
\hline $12 \mathrm{t}$ & 29.36 & 6.6 & 7.66 & 39.20 & 4.82 & 2.08 & 1.63 & 0.01 & 6.84 & 7.04 & 0.04 & 0.16 & 0.20 & 840 & 30 & 130 & Sandy Loam. \\
\hline SPC & 37.23 & 8.15 & 9.12 & 31.53 & 10.78 & 6.37 & 8.74 & 8.14 & 34.03 & 38.03 & 2.80 & 2.20 & 4.00 & & & & \\
\hline
\end{tabular}


Table 2 Evaluation of different rates of sawdust - piggery compost on the growth of maize weeks after planting

\begin{tabular}{|c|c|c|c|c|c|c|c|c|c|}
\hline \multirow[t]{2}{*}{ Treatment } & \multicolumn{3}{|c|}{ Plant height (cm) } & \multicolumn{2}{|c|}{ stem girth (mm) } & \multirow[b]{2}{*}{8} & \multicolumn{3}{|c|}{ Leaf Area $\left(\mathrm{cm}^{2}\right)$} \\
\hline & 4 & 6 & 8 & 4 & 6 & & 4 & 6 & 8 \\
\hline C 7.97 & $22.95 c$ & $50.39 \mathrm{c}$ & 10.11 & $18.59 \mathrm{c}$ & $24.23 c$ & 119.40 & \multicolumn{2}{|c|}{$576.41 c$} & $819.71 c$ \\
\hline 2 t 9.72 & $25.12 \mathrm{ab}$ & $55.43 \mathrm{~b}$ & 10.16 & $21.94 b$ & $25.72 \mathrm{c}$ & 173.60 & \multicolumn{2}{|c|}{$602.43 b$} & $921.34 \mathrm{ab}$ \\
\hline 4 t 7.88 & 25.33ab & $59.84 a$ & 9.50 & $22.30 \mathrm{~b}$ & $26.28 b$ & 120.60 & \multicolumn{2}{|c|}{$639.56 a$} & $958.63 a$ \\
\hline $6 \mathrm{t} 7.20$ & $36.00 \mathrm{a}$ & $60.70 \mathrm{a}$ & 10.56 & $26.00 \mathrm{a}$ & $30.76 a$ & 121.40 & \multicolumn{2}{|c|}{$685.51 \mathrm{a}$} & $983.34 \mathrm{a}$ \\
\hline 8 t 9.75 & $35.83 a$ & $59.23 \mathrm{a}$ & 10.56 & $26.67 \mathrm{a}$ & $30.06 a$ & 128.90 & \multicolumn{2}{|c|}{$664.81 \mathrm{a}$} & $988.84 a$ \\
\hline 10 t 9.15 & $33.45 a$ & $60.69 a$ & 10.78 & $25.47 \mathrm{a}$ & $31.10 \mathrm{a}$ & 123.60 & \multicolumn{2}{|c|}{$671.52 \mathrm{a}$} & $1172.71 \mathrm{a}$ \\
\hline 12 t 7.48 & $34.33 a$ & $59.98 a$ & 10.11 & $25.36 \mathrm{a}$ & $31.20 \mathrm{a}$ & 123.70 & \multirow{2}{*}{\multicolumn{2}{|c|}{$\begin{array}{c}668.82 \mathrm{a} \\
26.73\end{array}$}} & \multirow{2}{*}{$\begin{array}{c}1182.81 \mathrm{a} \\
56.56\end{array}$} \\
\hline LSD NS & 6.33 & 3.31 & NS & NS & 3.40 & NS & & & \\
\hline
\end{tabular}

Mean values on the vertical column with same letters are not significantly $(\mathrm{p} \leq 0.05)$ different, means separated by LSD.

\subsection{Yield Parameters}

At harvest, the cob weight of maize planted on soil amended with Sawdust - Piggery compost were significantly $(\mathrm{p} \leq 0.05)$ higher compared to control (Table 3). The application of ten tha ${ }^{-1}$ of sawdust - piggery compost significantly $(\mathrm{p} \leq 0.05)$ increased the cob weight of maize compared to other treatments. (20), reported that the incorporation of organic manure improves the yield of maize depending on the rate of application.

Table 3 Evaluation of different rates of sawdust - piggery compost on the yield and nutrient uptake of maize. ( $\mathrm{t}$ ha ${ }^{-1}$ )

\begin{tabular}{|l|c|c|c|c|c|c|}
\hline & Cob wt(t ha-1 & GY(t ha-1 & DMY(t ha-1 & N & P & K \\
\hline Control & $11.40 \mathrm{c}$ & $2.09 \mathrm{c}$ & $3.01 \mathrm{c}$ & $0.60 \mathrm{~d}$ & $1.20 \mathrm{~d}$ & $0.30 \mathrm{~d}$ \\
\hline 2 tonnes & $12.70 \mathrm{c}$ & $3.17 \mathrm{~b}$ & $4.35 \mathrm{ab}$ & $1.18 \mathrm{c}$ & $1.91 \mathrm{c}$ & $0.46 \mathrm{c}$ \\
\hline 4 tonnes & $12.99 \mathrm{c}$ & $3.28 \mathrm{~b}$ & $4.46 \mathrm{ab}$ & $1.46 \mathrm{~b}$ & $1.87 \mathrm{c}$ & $0.53 \mathrm{c}$ \\
\hline 6 tonnes & $14.32 \mathrm{c}$ & $3.63 \mathrm{a}$ & $4.95 \mathrm{c}$ & $1.53 \mathrm{~b}$ & $2.28 \mathrm{~b}$ & $0.63 \mathrm{~b}$ \\
\hline 8 tonnes & $17.59 \mathrm{~b}$ & $4.41 \mathrm{a}$ & $5.14 \mathrm{~b}$ & $1.69 \mathrm{~b}$ & $2.88 \mathrm{ab}$ & $0.77 \mathrm{~b}$ \\
\hline 10 tonnes & $21.82 \mathrm{a}$ & $4.60 \mathrm{a}$ & $5.48 \mathrm{~b}$ & $1.89 \mathrm{~b}$ & $2.92 \mathrm{ab}$ & $0.76 \mathrm{~b}$ \\
\hline 12 tonnes & $16.87 \mathrm{~b}$ & $3.96 \mathrm{a}$ & $6.53 \mathrm{a}$ & $2.29 \mathrm{a}$ & $3.33 \mathrm{a}$ & $1.17 \mathrm{a}$ \\
\hline LSD & 3.18 & 1.01 & 0.93 & 0.33 & 0.46 & 0.17 \\
\hline
\end{tabular}

The application of 10 tonnes per hectare of sawdust - piggery compost significantly $(\mathrm{p} \leq 0.05)$ increased the grain yield of maize compared to other treatments (Table 3). It has been reported that the application of compost influence physical, chemical and biological properties of soil and therefore influences growth and yield of crops especially maize (21). Increase in grain yield of maize can be achieved with the application of compost (22). (23), it was observed that there was significant $(\mathrm{p} \leq 0.05)$ increase in the yield of maize from the application of manure.

The dry matter yield of maize planted on soil amended with Sawdust - piggery compost were significantly ( $\leq \leq 0.05)$ higher compared to control (Table 3). (20) reported that the composted piggery manure had higher significant ( $\leq 50.05$ ) dry matter yield of maize compared to control. The application of twelve tonnes of Sawdust - piggery compost significantly $(\mathrm{p} \leq 0.05)$ increased the dry matter yield of maize compared to other treatments. This result also confirms the earlier work done (24), they reported increase in dry matter yield of plants when compost was applied at a higher rate. It was also reported (25), that the application of compost manure increased the yield of crops. 
The nutrients uptake of maize was significantly $(\mathrm{p} \leq 0.05)$ increased with the application of sawdust - piggery compost compared to the control. Nutrient's uptake was significantly $(\mathrm{p} \leq 0.05)$ higher with the application of 12 tonnes of sawdust - piggery compost compared to other treatments. Uptake of nitrogen, potassium and phosphorus were significantly $(\mathrm{p} \leq 0.05)$ increased with the application of 12 tonnes of sawdust - piggery compost. According to (26), fertilizer either inorganic or organic significantly $(\mathrm{p} \leq 0.05)$ increased the nutrient uptake of maize and their finding corroborate with the results obtained from this experiment. Also, according to (27), the application of organic fertilizer significantly $(\mathrm{p} \leq 0.05)$ enhanced the uptake of nitrogen, phosphorus and potassium in maize.

\section{Conclusion}

The application of sawdust - piggery compost improved the physical and chemical properties of the soils. It also improves the nutrient content and nutrient uptake by plants. Application of 8- $12 \mathrm{t} \mathrm{ha-1}$ of sawdust - piggery compost significantly $(\mathrm{P} \leq 0.05)$ increases the plants height, leaf area and stem girth of maize compared to other treatments. It was observed that $10 \mathrm{t} \mathrm{ha}^{-1}$ of sawdust - piggery compost significantly $(\mathrm{p} \leq 0.05)$ increased the cob weight and the grain yield of maize. In Conclusion, application of $10 \mathrm{t} \mathrm{ha}^{-1}$ of sawdust - piggery compost can be used to ameliorate degraded soil for improved soil nutrients for effective growth and yield of maize. The composted pig manure and sawdust help to reduce environmental pollution caused by improper waste disposal.

\section{Compliance with ethical standards}

\section{Disclosure of conflict of interest}

This was no conflicting interest among contributors.

\section{References}

[1] Tittonell P, Vanlauwe B, Corbeels M, Giller KE. Yield gaps, nutrient use efficiencies and response to fertilizers by maize across heterogeneous small holder Farms of Western Kenya. Plant Soil. 2008; 313: 19 - 37.

[2] Han S H, An JY, Hwang J, Kim SB and Park BB (2016). The effect of organic manure and chemical fertilizer on the growth and nutrient concentration of yellow poplar in a nursery system. Forest Science and Technology. 12 (3) : 137- 143. https://doi.org/10.1080/21580103.2015.//355827.

[3] Ajayi OC, FK Akinnifesi, S Gudeta, S Chakeredza. Adoption of renewable soil fertility replenishment technologies in the Southern African religion. Lesson learnt and the way forward. National Resume Forum. 2007; 31 : 306 317 .

[4] Barbieri PA, HE Echeverria, HRS Rozas, FH Andrade. Nitrogen use efficiency in maize as affected by Nitrogen availability and row spacing. Agron J. 2008; 100: 1094 - 1100.

[5] Okoko ENK,S Makworo. Evaluation of the effect of compost and inorganic fertilizer on maize yield in Nyamira District, Southwest Kenya. Kenya Agricultural Research Institute, Regional Research Centre, Kisii, Kenya. 2017.

[6] Bouyoucos CJ. Hydrometer method for making particle size analysis of Soil. Soil Science Society of America proceedings. 1962; 26: 464-465.

[7] IITA. Selected methods for soil and plant analysis. Manure series No. 1 IITA, Ibadan, Nigeria. 1979.

[8] Nelson DW, Sommers LS. Total carbon, and organic matter. In page, A.L. et al (eds). Methods of Soil analysis. Part 2. AgronMongr. 9 (2nd edition). 1982; 403-430.

[9] Bray RH,Kurtz LT. Determination of total nitrogen and available form of phosphorus in Soils. Soil Science Journal. 1945; 59: 45-49.

[10] Bremmer JM, Malvaney CS. Nitrogen total. In: methods of soil analysis Part 2. 2nd Edition (eds. A. L. page, R.H. Miller and D.R. Kenney). ASA. ASS. Monograph No. 9 Madison, USA. 1982; 595-624.

[11] Remison SU,Lucas EO. Effects of planting density on leaf area and productivity of two maize cultivars in Nigeria. Experimental Agriculture. 1982; 18: 98-100.

[12] Robert P. Compost creates acidic soil. 2015.

[13] Quédraogo E, Mandob A,Zombrés NP. Use of compost to improve soil properties and crop productivity under low input agricultural system in West Africa. Agriculture, Ecosystems and Environment. 2001; 84: 259 - 226. 
[14] Adejobi KB, Famaye AO, Oloyede AA, Oyedokun AV, Adeosun SA, Adeniyi DO. Effects of organo-minerals fertilizer and cocoa pod Hust ash on the Soil, Leaf chemical composition and Growth of coffee. Nigeria Journal of Soil Science. 2011; 45-49.

[15] Oyun MB, Fasinmirin J, Olutolaji O0,Ogunrinde OS. Growth of maize (Zea mays. L.) in reponse to varying organic fertilizer treatment. Applied tropical agriculture. 2013; 74-77.

[16] Ogbonna DN, Isirimah NO,Princewill E. Effect of organic waste Compost and Microbial activity on the growth of maize in the utisols in Port Harcourt, Nigeria. African Journal of Biotechnology. 2012; 11:12546 - 12554.

[17] Benton J,Jones Jr. Inorganic chemical fertilizers and their properties in plant nutrition and soil fertility manual. Second Edition. CRC Press. 2012; ISBN 978 - 1- 4398 - 1609 - 7.

[18] Aziz T, Ullah S, Scattar A, Nasim M, Farooq M,Khan MM. Nutrient Availability and Maize (Zea mays L.) growth in Soil amendment with organic manures. International Journal of Agriculture and Biology. 2010; 12: 621 - 624.

[19] Domingos Pereira Gama, Budi Praselya, Soemarno. Application of organic matter Entisol-soil affected soil moisture capacity and growth of maize (Zea mays .L.). International journal of Research - Granthaalayah. Volume 6 (ISS I): January. 2018; ISSN - 2350 - 0530 (0), ISSN - 2394 - 3629.

[20] Verma SK,Verma M. A text book of plant physiology. Biochemistry and Biotechnology, S. Chand and Company Limited, Ram Nagar, New Delhi, India. 2007; 111-113.

[21] Martin JH, Waldren RP,Stamp DL. Fourth Edition. Principles of field crop production New Jersey: Pearson Education Limited. 2006.

[22] Ayoola OT,Makinde EA. Performance of green maize and Soil nutrient changes with fortified cow dung. African Journal of Plant Sciences. 2008; 2(3): 19-22.

[23] Tejada M, Hernandez MT, Garcia C. Soil restoration, using composted plant residues: Effects on Soil properties. Soil and Tillage Research. 2009; 102: 109-117.

[24] Marere A, Kimbi GG,Nonga. Comparative effectiveness of yield and root growth of Amaranthus. African Journal of Science and Technology. 2001; 1(4): 14-21.

[25] Paulin B,0`Malley P. Compost production and use in horticulture, Volume Bulletin 4746. Western Australia Agriculture Authority. 2008.

[26] Ogungbe PW, Fagbola O (2008). Influence of Mycorrhiza and Organomineral Fertilizer Application on growth of maize cultivars in Nutrient Depleted soil. Nigerian Journal of Mycology 1, $111-118$.

[27] Tulsiram N, Mohan SM. Impact of integrated nutrient management on nutrient uptake and economics of maize (Zea mays L.). International Journal of Advanced Scientific Research. 2018; 3(2): 1-3. 